\title{
Multidimensional poverty of the ethnic tibetan farm and Herder households in Gansu province, China
}

\author{
Fan Yang ${ }^{1}$ (D) Krishna Paudel $^{2}$ (D) Tianhui Zhuang ${ }^{3 *}$ (iD) Yao Jiang ${ }^{4}$ (iD \\ ${ }^{1}$ Faculty of Social Development and Western China Development Studies, Sichuan University, Chengdu, Sichuan, China. \\ ${ }^{2}$ Department of Agricultural Economics and Agribusiness, Louisiana State University (LSU) and LSU AgCenter, Baton Rouge, Louisiana, \\ USA. \\ ${ }^{3}$ Southwest Center for Poverty Alleviation and Development Research, Sichuan Agricultural University, 611130, Chengdu, Sichuan, China. \\ E-mail: 769386851@qq.com. "Corresponding author. \\ ${ }^{4}$ College of Management, Sichuan Agricultural University, Chengdu, Sichuan, China.
}

ABSTRACT: Ethnic Tibetan farm and herder households (FHH) in Gansu Province, China are stricken with poverty. Solving the poverty problem in this or other poverty pockets across China has special importance for the country's political stability, ethnic unity, social well-being, and ecological security. This paper calculates the multidimensional poverty situation of ethnic Tibetan farm and herder households of Gansu Province, China by using the Alkire-Foster method. Twelve indicators are included in the multidimensional poverty indicator system. Results showed that 1$)$ in the single indicator measure, the adult family members received at least 9 th grade education $\left(x_{3}\right)$, the home toilet type $\left(x_{7}\right)$, and the labor availability $\left(x_{2}\right)$ showed a higher incidence of deprivation, 2) many FHH in the Tibetan areas of the Gansu Province are facing multidimensional poverty but the proportion of extreme poverty is very small, and 3) from the perspective of contribution rate, the adult family members received at least 9 th grade education $\left(x_{3}\right)$, labor availability $\left(x_{2}\right)$, self-health assessment $\left(x_{1}\right)$, home toilet type $\left(x_{7}\right)$, and school-age children dropout rate $\left(x_{4}\right)$ occupied the top five positions as obtained from the equal weight to dimensions (DEW) method.

Key words: Alkire-Foster method, farm and herder households, multidimensional poverty, poverty alleviation, Tibetan people.

Pobreza multidimensional da fazenda tibetana étnica e das famílias de Herder na província de Gansu, China

RESUMO: As fazendas tibetanas e lares de pastores na província de Gansu, na China, são atingidas pela pobreza. Resolver o problema da pobreza neste ou em outros aglomerados em toda a China tem importância especial para a estabilidade politica do país, a unidade étnica, o bem-estar social e a segurança ecológica. Esta pesquisa calcula a situação multidimensional da pobreza das famílias de fazendeiros e pastores tibetanos da Província de Gansu, usando o método Alkire-Foster. Doze indicadores estão incluídos no sistema multidimensional de indicadores de pobreza. Os resultados mostram que: 1) na medida de indicador único, os membros adultos da família receberam o grau de instrução até, pelo menos, a $9^{a}$ série (x3); o tipo de banheiro (x7) e a disponibilidade de mão-de-obra (x2) apresentam maior incidência de privação; 2) muitas FHH nas áreas tibetanas da Província de Gansu enfrentam pobreza multidimensional, mas a proporção de pobreza extrema é muito pequena e, 3) do ponto de vista da taxa de contribuição, os membros adultos da família receberam pelo menos a $9^{a}$ série (x3), disponibilidade (x2), a análise de auto-avaliação (x1), o tipo de banheiro domiciliar (x7) e a taxa de desistência de crianças em idade escolar (x4) ocuparam as cinco primeiras posições obtidas do método de peso igual a dimensões (DEW).

Palavras-chave: método de Alkire-Foster, casas de fazenda e pastores, pobreza multidimensional; alivio da pobreza; Povo tibetano.

\section{INTRODUCTION}

Tibetan people live predominantly in the Tibet Autonomous Region of China, but they also inhabit some pockets of Qinghai, Sichuan, Yunnan, and Gansu Provinces in China. In these areas inhabited by ethnic Tibetans, economic and social progress have been noteworthy, the people's income level is growing, living standards are increasing, and the regions are experiencing an overall economic growth. However, due to the fragile natural environment, remote locations, complex social relations, and sensitive politics, these regions are still seriously poverty stricken. Alleviating poverty in these areas not only improves people's livelihoods, but also promotes overall economic development and social stability in China. 
Gansu Tibetan area is unique, but it is also representative of the Tibetan dominant regions in the country. The Tibetan areas of Gansu Province include Gannan Tibetan Autonomous Prefecture and Tianzhu Tibetan Autonomous County. The Gannan Tibetan Autonomous Prefecture is one of China's ten Tibetan Autonomous Prefectures in the Southwest of Gansu Province. It is in the water conservation and supply areas of the Yangtze River and the Yellow River and is the intersection of Tibetan and Han cultures. It is called "the window of the Qinghai-Tibet Plateau" and "the springboard of Tibetan modernization." The Tianzhu Tibetan Autonomous County is in the middle of Gansu Province and south of Wuwei City, lying in the eastern part of the Hexi Corridor and the Qilian Mountains. It was the first region to apply for national regional autonomy after the establishment of the People's Republic of China.

We calculated a multidimensional poverty index of farmer and herder households in the Tibetan areas of Gansu Province. Our main objectives and contributions are as follows: First, we used primary data collected from a face-to-face interview survey to calculate the multidimensional poverty situation of a unique region (majority Tibetan region) and a unique ethnic group (Tibetans). Second, we used a variety of methods to calculate the weight of indicators to make the results more robust. Third, we identified indicators and dimensions of multidimensional poverty, which is helpful in guiding China's anti-poverty policy for Tibetans and other minority populations.

The remainder of this paper is organized as follows. In section 2 , we provide a literature review. In section 3, we present methods used in the paper. In section 4 , we introduce the study area and data collection process. In section 5 , we present results and provide some discussions. In section 6 , we conclude the paper by discussing the policy implications of the findings.

\section{LITERATURE REVIEW}

There has been some research on poverty alleviation in the Tibetan areas of China (LI, 2006; ZHU, 2010; LIAO, 2014a; WANG, 2016; ZHUANG, 2016). The related research focused on the three aspects of poverty, viz., description and quantitative measurement, micro explanation and macro analysis, and multidimensional constraints and coping strategies.

From the first aspect, the description and quantitative measurement of poverty in the Tibetan areas, the consensus is that the Tibetan areas face a serious poverty problem (LI, 2006; ZHU, 2010; LIAO, 2014a; WANG, 2016; ZHUANG, 2016).

The second aspect is the study of the causes of poverty in the Tibetan areas. At the microlevel, researchers mainly explained poverty of the Tibetan areas as related to human capital (QIN \& LU, 2012), social capital (LIAO \& LI, 2009), intergenerational transmission (LIAO, 2014b), and individual vulnerability (LI \& WANG, 2015). At the macro-level, many researchers interpreted poverty of the Tibetan areas from the perspectives of geography, climate, history, culture, religion, and politics (YANG, 2005; LI, 2006; YAN et al., 2011; QIN \& LU, 2012; DU \& YU, 2013).

The third aspect contained the multidimensional constraints and strategies of poverty alleviation in the Tibetan areas. The multidimensional constraints of poverty alleviation in the Tibetan areas included both seriousness of poverty and poverty alleviation policies (DU \& ZHAO, 2010). As for the anti-poverty measures in the Tibetan areas, SHEN (2015) advocated adhering to the basic principles of combining 1) external assistance with selfdevelopment, 2) government, market, and society with the poor themselves, and 3) poverty reduction with precision and poverty alleviation in the region. Based on the above principles, many anti-poverty measures have been put forward, including attempting to help the poor people out of poverty by raising their economic and human capital capacities (QIN \& LU, 2012; HUA et al., 2017), through the development of tourism projects (ROSSETTO et al., 2007; GENG et al., 2016), and unique local cottage industries (LUO \& XIE, 2016), by converting ecological resources into ecological assets (FOGGIN, 2008; DU \& YU, 2013), and through the development of basic and equal public services (LAN \& YANG, 2016; LIU et al., 2018).

From the above review, a lot of valuable research results have been obtained regarding poverty governance in the Tibetan areas, which provide a good reference point for further study of poverty in those areas. Of course, there are still some points that were ignored by past researchers. With the development of the multidimensional poverty theory, it is the consensus that poverty is not formed in a unidimensional manner. Consequently, the theory, methodology, and empirical research on poverty are transformed from single dimensional poverty to multidimensional poverty. Specifically, multidimensional poverty theory is gradually being improved (ALKIRE \& FOSTER, 2011a, 2011b; ALKIRE et al., 2015b). The Alkire-Foster (AF) method is gradually becoming the basic method of 
multidimensional poverty measurement (ALKIRE et al., 2015a). In the empirical field, studies of multidimensional poverty measurement in different regions among poor groups are increasing and have become the major field of poverty research (WANG \& ALKIRE, 2009; GUO \& WU, 2012; YU, 2013; ALKIRE \& SANTOS, 2014; ZHANG \& ZHOU, 2015; ROGAN, 2016).

There is limited research on the multidimensional poverty measurement for the Tibetan areas, which have unique political, economic, and environmental characteristics. When multiple indicators are used to measure poverty, policymakers may be interested in knowing if $\mathrm{FHH}$ are seriously impacted by one or more indicators of poverty. Policymakers can then focus on these identified indicators to improve the livelihood and uplift FHH from poverty. Addressing poverty in minority-inhabited areas is essential for keeping stability and harmony among different groups of people in the country.

Public policies regarding poverty research and poverty alleviation have always paid greater attention to the understanding and measurement of poverty. It can be said that poverty is accompanied by the history of human development, and the history of human development is, to some extent, the history of human beings' struggles against poverty. Traditional understanding of poverty mainly centers on income, which means the income of the family or individual is too low to meet basic daily needs. As research in poverty progressed further, the disadvantages of defining poverty based on income became too obvious. One of the main reasons is because it is difficult to acquire accurate income information from households (ZILIAK, 2015).

The connotation of poverty has gradually evolved from narrow income poverty to generalized human poverty. At present, the international academic community has gradually formed a consensus that poverty is not only a lack of income, but also deprivation of the right to human development, such as deprivation of health and longevity, good education, and the opportunity to live a dignified life (UNDP, 1997).

The Multidimensional Poverty Index (MPI) uses different factors to determine poverty beyond income-based lists (UNDP, 2010). Evolution of poverty measurement to the multidimensional poverty index has a long history. Sociologists and anthropologists have all paid attention to the diversity of poverty. MORRIS (1979) puts forward the physical quality of life index to measure poverty. Hagenaars
(1987) measures poverty from two dimensions: income and leisure. However, SEN $(1985 ; 1999)$ has done pioneering research on capacity and put it into the framework of poverty analysis. Based on Sen's work, the United Nations Development Program (UNDP) established the Human Development Index (HDI) in 1990, and then developed the HDI to measure and judge poverty situations in a country or region from several dimensions (UNDP, 1997). In 2010, the UNDP worked with the University of Oxford in the UK to construct the MPI to measure poverty from three dimensions (health, education, and living standard) constituting 10 different indicators (UNDP, 2010).

The multidimensional poverty measure has long been a central topic in poverty research. For example, FOSTER et al. (1984) design a class of decomposable poverty measures. ZHENG (1997) analyzes and evaluated a series of poverty indicators. In 2007, Oxford University created OPHI. Sabina Alkire, the director of the OPHI, set up a research team committed to the research of multidimensional poverty measurement methods. ALKIRE (2007) believed that the multidimensional poverty measurement associated with the ability approach can provide more accurate information, making it easier to identify people's ability deprivation. Subsequently, ALKIRE \& FOSTER (2011a) proposed the method of multidimensional poverty identification, summation, and decomposition and named it the AF method.

There exists a plethora of studies that have used multidimensional methods to measure poverty (DEUTSCH \& SIBER, 2005; BATANA, 2008; CHAKRAVARTY et al., 2008; ALKIRE et al., 2015b). For example, DEUTSCH \& SILBER (2005) measure the multidimensional poverty of Israel in 1995 using four methods, viz., the theory of fuzzy sets, information theory, efficiency analysis, and axiomatic derivations of poverty indices. CHAKRAVARTY et al. (2008) estimated the multidimensional poverty of many countries in the world from 1993 to 2002 using Watts' multidimensional poverty index. BATANA (2008) measured multidimensional poverty in SubSaharan Africa by applying the AF method. ALKIRE \& SETH (2008) calculated multidimensional poverty in India by using the AF method. BATTISTON et al. (2013) measured the multidimensional poverty of six Latin American countries using the AF method. ALKIRE et al. (2014) gauged multidimensional poverty for European Union Statistics on Income and Living Conditions countries using the AF method.

Researchers have also used the AF method to calculate multidimensional poverty in 
China. ZHANG \& ZHOU (2015) analyzed breadth, depth, and intensity of multidimensional poverty in China and conducted urban-rural decomposition and comparison by using the Chinese Health and Nutrition Survey (CHNS) data from 1991 to 2011. They used the AF method with 12 indicators. ZHANG \& FENG (2016) estimated the multidimensional poverty of 451 women who are employed in the nanny occupation in Beijing, China by using the AF method and 11 indicators. We also used the AF method to calculate and identify poverty indicators of the Tibetan FHH in Gansu province, China.

\section{METHODS}

\section{Selection and definition of multidimensional poverty index}

We used the MPI to measure the status of multidimensional poverty of farm and herder households in the Tibetan areas of Gansu Province, China. Based on the actual situation of China and the Tibetan areas, we adjusted the specific indicators in MPI to capture local realities. We considered 12 indicators that reflected three dimensions to measure the MPI of FHH. These indicators are shown in table 1. The three dimensions used are health, education, and living standard. The Oxford Poverty and Human Development Initiative (OPHI) also used the three dimensions (ALKIRE \& ROBLES, 2017), but our indicators are more reflective of the Tibetan FHH in the study area.

In health, we choose self-health assessment $\left(x_{1}\right)$ and labor availability $\left(x_{2}\right)$. The importance of health to a person is self-evident. If an individual suffers from a chronic or severe health issue, he/she will easily fall into poverty because of an inability to pay medical bills or an inability to work (RACINE, 2016). In most cases, in developing countries, the individual suffering from health issues can affect the quality of life for all household members. If all family members' health is good, we argued that this indicator of self-health assessment (x1) is not poor; otherwise it is poor. Here good health means that family members do not have any debilitating health issues that require them to visit a doctor or a hospital on a regular basis. Labor creates value and labor brings income. Lack of labor availability is an important cause of poverty (BLUNDELL, 2018). Therefore, labor availability $\left(x_{2}\right)$ is also crucial in preventing poverty. If all the adult family members in a household are available laborers, we think that this indicator of labor availability $\left(x_{2}\right)$ is not poor; otherwise it is poor.

Table 1 - Dimensions, indicators, and poverty cutoff of each indicator.

\begin{tabular}{|c|c|c|c|}
\hline Dimension & Number & Indicator & Deprivation cutoff \\
\hline \multirow{2}{*}{ Health } & 1 & Self-health assessment $\left(x_{1}\right)$ & $\begin{array}{l}\text { Household head's evaluation of family members health, if all } \\
\qquad \operatorname{good}=0 ; \text { otherwise }=1\end{array}$ \\
\hline & 2 & Labor availability $\left(x_{2}\right)$ & $\begin{array}{l}\text { If all the adult family members in the household are available } \\
\qquad \text { labors }=0 \text {; otherwise }=1\end{array}$ \\
\hline \multirow{2}{*}{ Education } & 3 & $\begin{array}{l}\text { Adult family members received 9th } \\
\text { grade education }\left(x_{3}\right)\end{array}$ & $\begin{array}{l}\text { If all adult family members have formal schooling equal or } \\
\text { above } 9 \text { years }=0 \text {; otherwise }=1\end{array}$ \\
\hline & 4 & School-age children dropout $\left(x_{4}\right)$ & $\begin{array}{l}\text { If school age children are not attended in the school=1; } \\
\text { otherwise }=0\end{array}$ \\
\hline \multirow{8}{*}{ Living standard } & 5 & Per capita housing area $\left(x_{5}\right)$ & $\begin{array}{l}\text { Per capita housing areas is less than } 25 \text { square meters }=1 \text {; per } \\
\text { capita housing areas is equal to } 25 \text { square meters or more }=0\end{array}$ \\
\hline & 6 & Housing quality $\left(x_{6}\right)$ & Dilapidated building $=1 ;$ not dilapidated building $=0$ \\
\hline & 7 & Home toilet type $\left(x_{7}\right)$ & No toilet or dry toilet $=1$; flush toilet $=0$ \\
\hline & 8 & $\begin{array}{l}\text { Animal shed is within the house } \\
\text { where people live }\left(x_{8}\right)\end{array}$ & Yes $=1 ;$ otherwise $=0$ \\
\hline & 9 & Sources of drinking water $\left(x_{9}\right)$ & $\begin{array}{l}\text { Tap water or well water with well depth of } 5 \text { meters or } \\
\qquad \text { more }=0 ; \text { otherwise }=1\end{array}$ \\
\hline & 10 & Household electricity supply $\left(x_{10}\right)$ & Continuous power supply availability $=0$; otherwise $=1$ \\
\hline & 11 & Household fuel supply $\left(x_{11}\right)$ & Fuel supply is enough for cooking purpose $=0$; otherwise $=1$ \\
\hline & 12 & Number of consumer durables $\left(x_{12}\right)$ & $\begin{array}{l}\text { The number of household consumer durables (such as TV, } \\
\text { washing machine, car, etc.) is less than } 3=1 \text {; otherwise }=0\end{array}$ \\
\hline
\end{tabular}

Note: If a household has a value of 1 on an indicator, it means that the household is deprived on this indicator, viz., the household is poor on this indicator. 
In education, we choose whether adult family members received at least 9 th grade education $\left(x_{3}\right)$ and the rate at which school-age children drop out $\left(x_{4}\right)$. China mandates nine-years of compulsory education. If the nine years of compulsory education are completed, the individual is thought to have mastered the basic literacy skills and have basic human capital (ZHANG, 2014). Therefore, we believed that if all adult family members have formal schooling equal to or above nine years, this indicator of adult family members having received at least 9 th grade education $\left(x_{3}\right)$ is not poor; otherwise it is poor. If school age children of a family are not attending school, the family is likely to encounter the risk of poverty in the future due to a lack of human capital (MIHAI et al., 2015). We considered the indicator of school-age children having dropped out $\left(x_{4}\right)$ is poor, otherwise it is not poor.

In living standard, we choose per capita housing area $\left(x_{5}\right)$, housing quality $\left(x_{6}\right)$, home toilet type $\left(x_{7}\right)$, animal shed is within the house where people live $\left(x_{8}\right)$, sources of drinking water $\left(x_{9}\right)$, household electricity supply $\left(x_{10}\right)$, household fuel supply $\left(x_{11}\right)$, and number of consumer durables $\left(x_{12}\right)$. Housing area and housing quality are two different aspects of housing safety. A house could be big with a thatched roof and mud wall, but it may not have quality. Therefore, housing area and housing quality should be two separate indicators. In the work of poverty alleviation in the rural areas of China, families whose per capita housing area is less than 25 square meters are defined as families with housing difficulties. Therefore, if the per capita housing area of a family is less than 25 square meters, we define the indicator of per capita housing area $\left(x_{5}\right)$ as poor. Otherwise, if the per capita housing area of a family is equal to 25 square meters or more, we defined the indicator of per capita housing area $\left(x_{5}\right)$ as not poor. If the house of a family is a dilapidated building, the indicator of housing quality $\left(x_{6}\right)$ is poor, otherwise it is not poor. The quality of the toilet is not only a reflection of living standards, but it is also closely related to health. Indoor plumbing and a flushing type of toilet are good for sanitation and preventing diseases. Therefore, if a family has a flushing toilet, the family is not poor on this indicator of home toilet type $\left(x_{7}\right)$; otherwise it is poor. Having an animal shed within the house where people live can easily endanger human health. Tibetans have a tradition of keeping animals within a shed that shares the same structure where humans also live. Therefore, if an animal shed is within the house where people in a family reside, the family is poor on this indicator of animal shed is within the house where people live $\left(x_{8}\right)$; otherwise it is not poor. Water is the source of life, and its role in human health and quality of life is self-evident. Quality of tap water and deep well water can be guaranteed to some extent. Therefore, if a family has tap water or well water with a well depth of 5 meters or more, the family is not poor on this indicator of sources of drinking water $\left(x_{9}\right)$; otherwise it is poor. Electricity and fuel can determine the quality of life of a family to a large extent. Therefore, if a family has enough electricity and fuel, we believe that the family is not poor on the household electricity supply $\left(x_{10}\right)$ and household fuel supply $\left(x_{11}\right)$ indicators; otherwise it is poor. To some extent, the number of durable consumer goods reflects the richness and quality of life of a family. We define that if a household has less than 3 consumer durables (such as a TV, washing machine, car, etc.), the household is poor on the indicator of number of consumer durables $\left(x_{12}\right)$; otherwise it is not poor.

\section{AF method}

This paper uses the AF method developed by ALKIRE \& FOSTER (2011a) to measure the multidimensional poverty of FHH in the Tibetan areas of Gansu Province. The appeal of the AF method lies in its ability to introduce a more inclusive approach to identifying poor people. It can be easily decomposed to find a dimension specific contribution or values by population subgroups (YU, 2013).

\section{Weight assigned to dimension and indicator}

One of the important steps of the AF method is the weight assigned to dimension and indicator variables. There is some arbitrariness in assigning the weight. In order to ensure the accuracy of measurement results, we used six methods to calculate the weight of each indicator. These methods are: the analytic hierarchy process (AHP), equal weight to indicators (IEW), equal weight to dimensions (DEW), entropy method (EM), principal component analysis (PCA), and the factor analysis (FA). Although, we calculated the multidimensional poverty index using all of these methods, for the sake of brevity, we described the results obtained only from the DEW method.

AHP

This paper calculated the weight according to the introduction to AHP by SAATY (1987). AHP needs to judge the importance of each indicator. We invited experts on poverty to rank the importance of indicators. The indicators ranking according to importance is shown in table 2 . 
Table 2 - Indicator ranking according to importance in AHP

\begin{tabular}{lc}
\hline Indicator & Ranking \\
\hline School-age children dropout $\left(x_{4}\right)$ & 1 \\
$\begin{array}{l}\text { Adult family members received at least 9th } \\
\text { grade education }\left(x_{3}\right)\end{array}$ & 2 \\
Self-health assessment $\left(x_{1}\right)$ & 3 \\
Labor availability $\left(x_{2}\right)$ & 4 \\
Sources of drinking water $\left(x_{9}\right)$ & 5 \\
Animal shed is within the house where people & 6 \\
live $\left(x_{8}\right)$ & 7 \\
Home toilet type $\left(x_{7}\right)$ & 8 \\
Housing quality $\left(x_{6}\right)$ & 9 \\
Household fuel supply $\left(x_{11}\right)$ & 10 \\
Per capita housing area $\left(x_{5}\right)$ & 11 \\
Household electricity supply $\left(x_{10}\right)$ & 12 \\
\hline Number of consumer durables $\left(x_{12}\right)$ & \\
\hline
\end{tabular}

Note: AHP means the analytic hierarchy process.

IEW

IEW's weight is calculated as:

Weight $_{i}=\frac{1}{n}$

where welght $_{\mathrm{i}}$ is the weight of indicator $i$, and $n$ is the total number of indicators.

\section{$D E W$}

DEW's weight is calculated as:

Weight $_{i}=\frac{1}{D} \times \frac{1}{N_{d}}$

where Welght is the weight of indicator $i$ in dimension $d, D$ is the total numbers of dimensions, and $N_{d}$ is the total number of indicators in a given dimension $d$.

\section{$E M$}

Suppose a total of $m$ samples, where $n$ are the evaluation indicators, and $x_{i j}$ is the value of the indicator $j$ of the sample $i$. The proportion of the indicator $i$ of the sample $i$ is $l_{i j}$ :

$l_{i j}=\frac{x_{i j}}{\sum_{i=1}^{m} x_{i j}}$

The entropy of the indicator $j$ is $s_{j}$ :

$s_{j}=-k \sum_{i=1}^{m} l_{i j} \ln l_{i j}$

And,

$k=\frac{1}{\ln m}$

The difference coefficient of indicator $j$ is $g_{j}$ :

$g j=1-s j$

The weight of indicator $j$ is $h_{j}$ :

$h_{j}=\frac{g_{j}}{\sum_{j=1}^{n} g_{j}}$
Principal component analysis (PCA)

PCAhelps to reduce the number of variables in an analysis by using a series of uncorrelated linear combinations of the variables that contain most of the variance. Most of the variance in an eigenvector decomposition is captured in the first component. Therefore, we used the weight of each indicator from the first component in the MPI calculation. Details related to the PCA can be found in PERES-NETO et al. (2003) and JOLLIFFE et al. (2002).

\section{Factor analysis (FA)}

We used the FA method to assign weight to each indicator variable. Factor analysis is a statistical technique that helps to reduce data. It uses a linear combination of the variables that contain most of the information to reduce the total number of variables used in the analysis. Interested readers can refer to MULAIK (2010) for details related to FA.

Weights of each indicator calculated by the six methods are shown in table 3 .

\section{Poverty cutoff (K)}

One critical step in multidimensional poverty measurement is to choose the proportion of indicators in which someone must be considered deprived and considered as multi dimensionally poor; in the AF method this is the poverty cutoff $(K) . K$ can be in the range of 0 to $100 \%$. The choice of a specific $K$ value depends on the preferences of researchers or policymakers, specific circumstances of a society, and the reason for calculation. There will be a large proportion of the population that is identified as poor if the $K$ is too small, which might cause confusion and even create political displeasure. Conversely, if the value of the $K$ is set too large, only a small proportion of people will be identified as multi dimensionally poor, which could also mislead policy makers. Generally, if $\mathrm{K}=30 \%$ or more than $30 \%$, this is defined as multidimensional poverty, which is a general norm. Therefore, according to the practice of existing research (YU, 2013; ALKIRE \& SANTOS, 2014; ROGAN, 2016 ), we mainly focus on the situation when $K=30 \%$.

\section{STUDY AREA AND DATA COLLECTION}

\section{Study area}

The study area of this paper is the Tibetan areas of Gansu Province, China (Figure 1). The study area consisted of eight county-level administrative units (Hezuo County, Zhouqu County, Zhuoni County, Lintan County, Diebu County, Xiahe County, Luqu County, and Maqu County) that fall under 
Table 3 - Weight of each indicator calculated by six methods.

\begin{tabular}{|c|c|c|c|c|c|c|c|}
\hline Dimension & Indicator & AHP & IEW & DEW & EM & PCA & FA \\
\hline \multirow{2}{*}{ Health } & Self-health assessment $\left(x_{1}\right)$ & 0.118 & 0.083 & 0.167 & 0.082 & 0.113 & 0.164 \\
\hline & Labor availability $\left(x_{2}\right)$ & 0.039 & 0.083 & 0.167 & 0.096 & 0.144 & 0.088 \\
\hline \multirow[t]{2}{*}{ Education } & $\begin{array}{l}\text { Adult family members received at least } \\
\text { 9th grade education }\left(x_{3}\right)\end{array}$ & 0.099 & 0.083 & 0.167 & 0.107 & 0.019 & 0.131 \\
\hline & School-age children dropout $\left(x_{4}\right)$ & 0.495 & 0.083 & 0.167 & 0.066 & 0.038 & 0.119 \\
\hline \multirow{8}{*}{ Living standard } & Per capita housing area $\left(x_{5}\right)$ & 0.009 & 0.083 & 0.042 & 0.090 & 0.044 & 0.102 \\
\hline & Housing quality $\left(x_{6}\right)$ & 0.062 & 0.083 & 0.042 & 0.072 & 0.179 & 0.074 \\
\hline & Home toilet type $\left(x_{7}\right)$ & 0.022 & 0.083 & 0.042 & 0.107 & 0.074 & 0.045 \\
\hline & $\begin{array}{l}\text { Animal shed is within the house where } \\
\text { people live }\left(x_{8}\right)\end{array}$ & 0.053 & 0.083 & 0.042 & 0.085 & 0.101 & 0.002 \\
\hline & Sources of drinking water $\left(x_{9}\right)$ & 0.043 & 0.083 & 0.042 & 0.089 & 0.018 & 0.074 \\
\hline & Household electricity supply $\left(x_{10}\right)$ & 0.025 & 0.083 & 0.042 & 0.064 & 0.130 & 0.041 \\
\hline & Household fuel supply $\left(x_{11}\right)$ & 0.024 & 0.083 & 0.042 & 0.090 & 0.057 & 0.091 \\
\hline & Number of consumer durables $\left(x_{12}\right)$ & 0.012 & 0.083 & 0.042 & 0.052 & 0.083 & 0.066 \\
\hline
\end{tabular}

Note: AHP: analytic hierarchy process; IEW: indicator equal weight; DEW: dimension equal weight; EM: entropy method; PCA: principal component analysis; FA: factor analysis.

the jurisdiction of the Gannan Tibetan Autonomous Prefecture, and Tianzhu Tibetan Autonomous County, which falls under the jurisdiction of the Wuwei City.

\section{Data collection}

The data used in this paper is from the interview survey conducted by the authors from July-
August of 2016. In order to ensure the reliability of the data and better reflect the multidimensional poverty status of FHH in the Tibetan areas of Gansu Province, we organized a field visit to Hezuo County. Then the research team designed a questionnaire using the information gathered from the field visit and carried out a preliminary investigation. Based

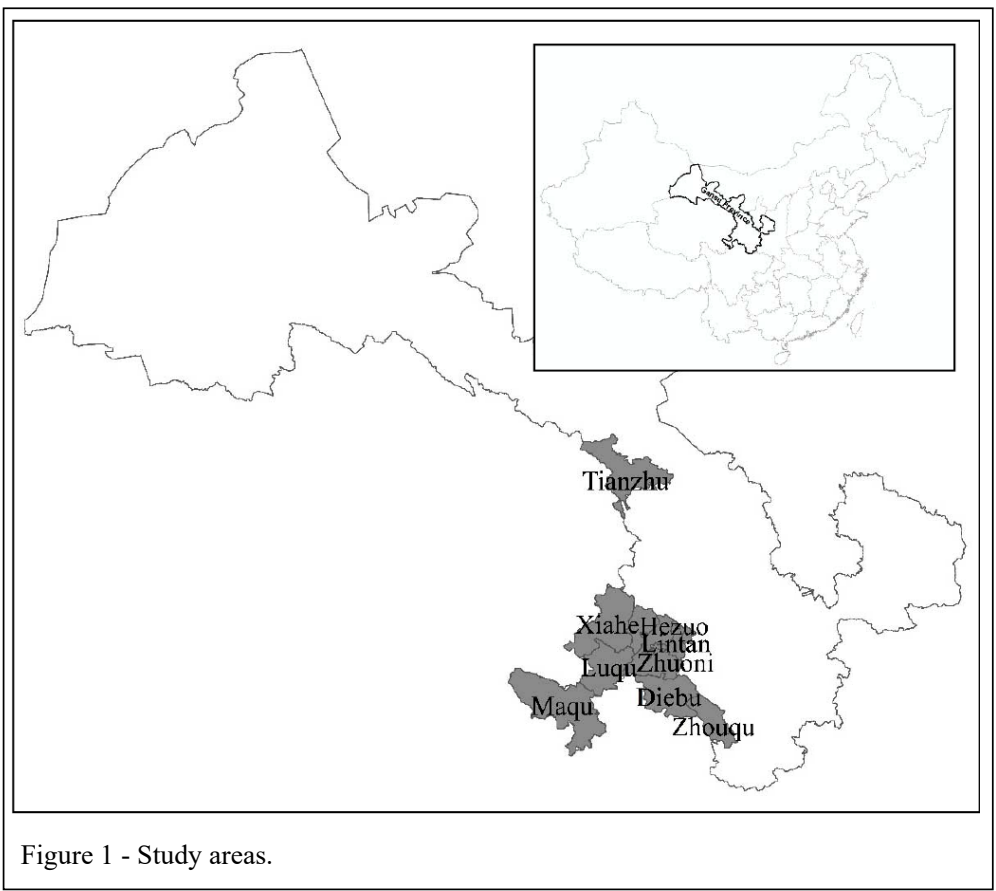

Ciência Rural, v.49, n.8, 2019. 
on the preliminary investigation, the questionnaire was modified to that used for formal investigation. The stratified random sampling methods have been adopted to select samples in the formal investigation, and sample households were randomly selected from the nine counties. Specifically, one township was randomly selected from each county, and two villages were randomly selected from each township. Thirtyfive households were randomly surveyed in each village. After eliminating some questionnaires with inconsistent answers, in total, 559 household heads were interviewed to make up the sample of this study. Specifically, 65 questionnaires were collected from Hezuo County, 58 from Zhouqu County, 61 from Zhuoni County, 65 from Lintan County, 63 from Diebu County, 63 from Xiahe County, 59 from Luqu County, 64 from Maqu County, and 61 from Tianzhu County.

\section{RESULTS AND DISCUSSIONS}

\section{Poverty incidence of each indicator}

Incidence of poverty for each indicator is calculated according to the deprivation cutoffs shown in table 1. Results are shown in figure 2. As seen in figure 2, the top three indicators in the incidence of poverty are the adult family members having received at least 9th grade education $\left(x_{3}, 91.23 \%\right)$, home toilet type $\left(x_{7}, 90.52 \%\right)$, and labor availability $\left(x_{2}, 48.84 \%\right)$. The incidences of poverty for these three indicators are high among FHH. Nine-years of compulsory education were implemented in 1986 in China. Any individuals who is currently 40 or above years old, did not have to follow this rule. This has resulted in incidence of poverty of the adult family members, which received formal education $\left(x_{3}\right)$ as the highest. Because of living habits, financial resource shortage, and vast natural space, the large majority of households in Tibet use dry toilets. Therefore, poverty is high in homes with dry toilet $\left(x_{7}\right)$.

In the second echelon, the following indicators exert impact: per capita housing area $\left(x_{5}, 34.35 \%\right)$, household fuel supply $\left(x_{11}, 33.27 \%\right)$, sources of drinking water $\left(x_{9}, 32.20 \%\right)$, animal shed is within the house where people live $\left(x_{8}, 25.05 \%\right)$, self-health assessment $\left(x_{1}, 21.83 \%\right)$, and the housing quality $\left(x_{6}, 11.81 \%\right)$. Incidences of poverty for these indicators are between $10 \%-40 \%$.

Poverty incidence of school-age children who drop out $\left(x_{4}, 8.59 \%\right)$, household electricity supply $\left(x_{10}, 7.34 \%\right)$, and number of consumer durables $\left(x_{12}\right.$, $3.76 \%$ ) are below $10 \%$. This reflects that the incidences of poverty for these three indicators are low. It also

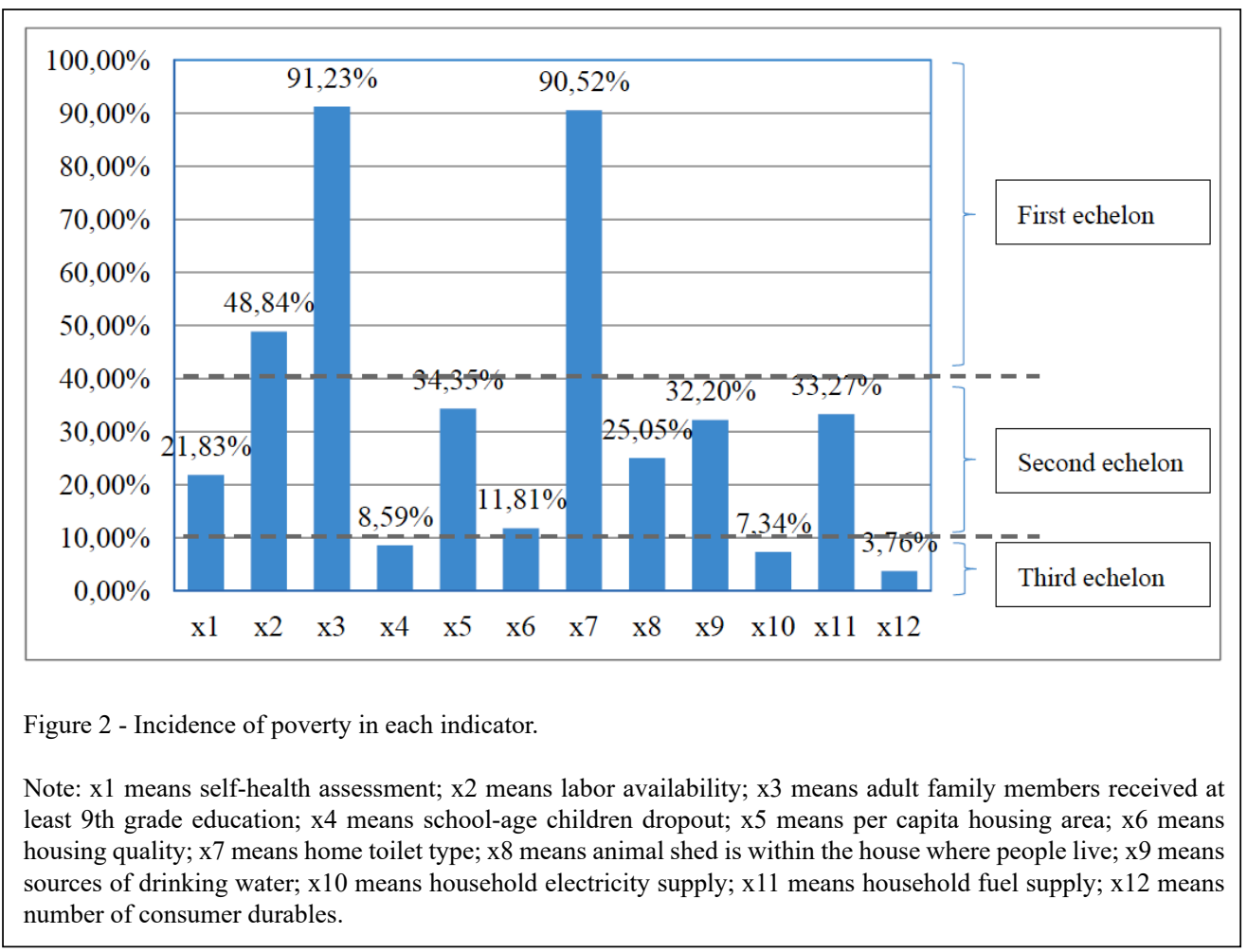

Ciência Rural, v.49, n.8, 2019. 
reflects these indicators' small contribution to the multidimensional poverty index. The above result of the dropout rate of school-age children showed that the nineyears of compulsory education has been implemented well in the Gansu Tibetan region. The result of electricity supply showed that electric power in the Gansu Tibetan area has been guaranteed effectively.

Distribution of the number of deprivation indicators

The distribution of the number of deprivation indicators is shown in table 4. The percentage of non-deprived households is only $1.25 \%$. This reflected that the vast majority of $\mathrm{FHH}$ exhibit one or more indicators of poverty. Percentage of seven indicators or more for the deprived households is no more than $10 \%$. This reflected that the proportion of extreme poverty in FHH is very small. The largest percentage of households are deprived on four indicators $(26.65 \%)$. This reflects that some households in the Tibetan area of Gansu are indeed facing multidimensional poverty.

\section{Multidimensional poverty measurement}

Multidimensional poverty headcount ratio

Figure 3 presents the multidimensional poverty headcount ratio $(H)$ of $\mathrm{FHH}$. We can observe
Table 4 - Number and percentage of households showing deprivation in poverty indicators.

\begin{tabular}{lcc}
\hline $\begin{array}{l}\text { Number of } \\
\text { deprivation } \\
\text { indicators }\end{array}$ & $\begin{array}{c}\text { Number of the poor } \\
\text { households }\end{array}$ & $\begin{array}{c}\text { Percentage of the } \\
\text { poor households } \\
(\%)\end{array}$ \\
\hline 0 & 7 & 1.25 \\
1 & 10 & 1.79 \\
\hline 2 & 50 & 8.94 \\
\hline 3 & 142 & 25.40 \\
\hline 4 & 149 & 26.65 \\
\hline 5 & 108 & 19.32 \\
\hline 6 & 52 & 9.30 \\
\hline 7 & 29 & 5.19 \\
\hline 8 & 10 & 1.79 \\
9 & 2 & 0.36 \\
\hline
\end{tabular}

that with the increase in $K$, the value of $H$ decreases gradually. When $K=10 \%$ in the DEW method, the $H$ value is above 0.959 . When $K=20 \%$, the $H$ value is 0.945 . When $K=30 \%$, the $H$ value is 0.572 . When $K=70 \%$, the $H$ value is below 0.1 . When $K=80 \%$, the $H$ value is below 0.01 . When $K=90 \%$, the $H$ value is equal to 0 . Results of other methods showed a similar

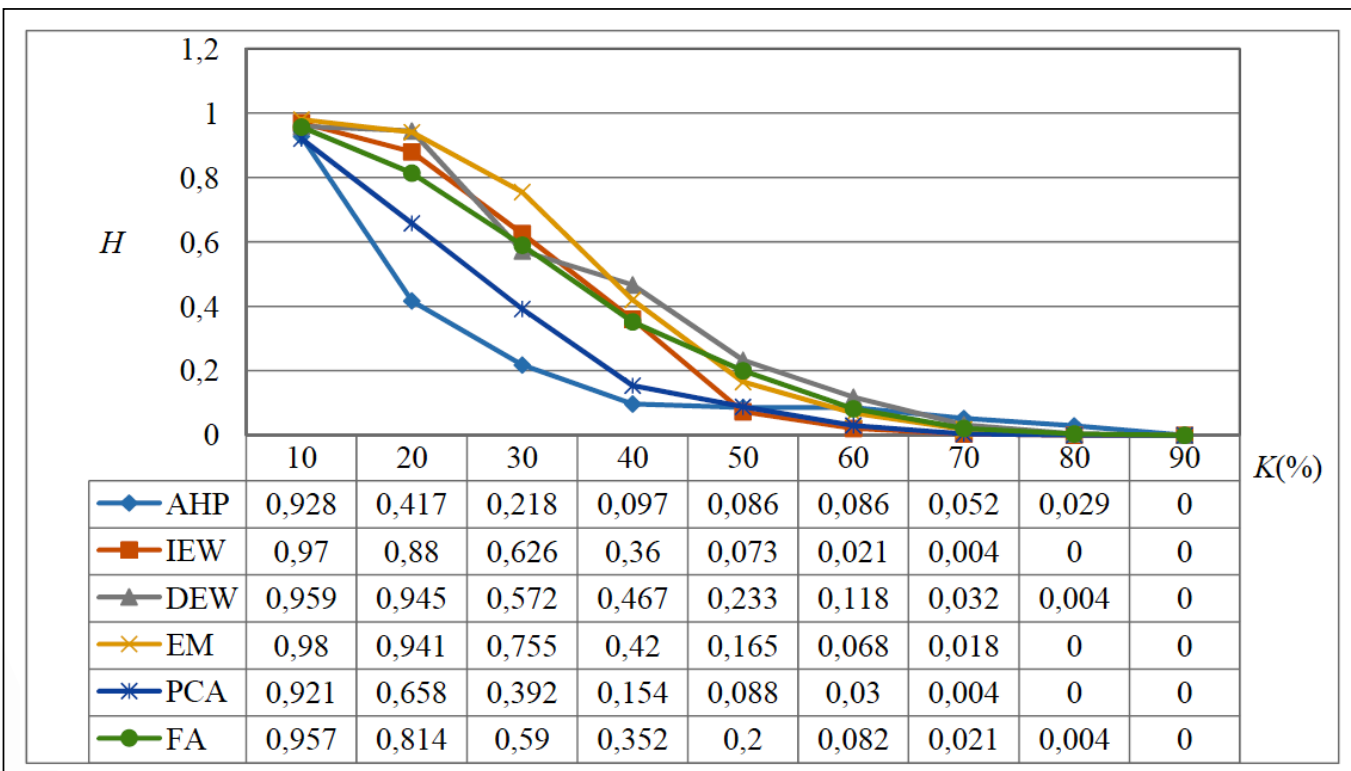

Figure 3 - H calculated by six weighting methods.

Note: $\mathrm{H}$ is multidimensional poverty headcount ratio; $\mathrm{K}$ is poverty cutoff; AHP means the analytic hierarchy process; IEW means giving each indicator the equal weight; DEW means giving each dimension the equal weight; EM means the entropy method; PCA means the principal component analysis; FA means the factor analysis. 
trend. The above results showed that most FHH are facing multidimensional poverty but the proportion in extreme poverty is very small.

$M P I$

The MPIs of FHH are shown in figure 4. We observed that with the increase in K, MPIs in the DEW method showed a gradual downward trend. When $K=10 \%$, the $M P I$ of $\mathrm{FHH}$ is 0.381 . When $K=20 \%$, the $M P I$ is 0.379 . When $K=30 \%$, the $M P I$ is 0.283 . When $K=60 \%$, the $M P I$ is below 0.1 . When $K=80 \%$, the $M P I$ is below 0.01 . When $K=90 \%$, the $M P I$ is equal to 0 . Results of other methods showed a similar trend. The above results also showed that most FHH are facing multidimensional poverty, but the proportion of extreme poverty is very small. This means that the poverty alleviation work done in the Gansu Tibetan area has achieved some results, but it still has a long way to go.

We calculated the correlation coefficients of MPI obtained by different weight methods in table 5. Results showed that the correlation coefficients of MPI calculated by different weight methods are relatively high-no lower than 0.890 , which means that the results are relatively robust.

\section{Contribution of each Indicator to MPI}

Generally, as stated in methods, if $K=30 \%$ or more than $30 \%$ this indicated multidimensional poverty. The contribution of each indicator to $M P I$ when $K=30 \%$ is shown in table 6 .

Table 6 showed that the contribution of each indicator to $M P I$ when $K=30 \%$ is different in all methods. The greatest contributor to MPI in the DEW method is the variable of whether adult family members received at least 9th grade education $\left(x_{3}\right)$. The second important indicator variable is labor availability $\left(x_{2}\right)$, and the third important indicator is the self-health assessment $\left(x_{1}\right)$. This showed that these three indicators have an important influence on multidimensional poverty among FHH. Therefore, FHH's education, labor skills, and health are facing serious deprivations.

The contribution rate of the variables identified as home toilet type $\left(x_{7}\right)$, the school-age children dropout rate $\left(x_{4}\right)$, the per capita housing area $\left(x_{5}\right)$, the household fuel supply $\left(x_{11}\right)$, the sources of drinking water $\left(x_{q}\right)$, the animal shed is within the house where people live $\left(x_{8}\right)$, and the housing quality $\left(x_{6}\right)$ is $0.078,0.050,0.038,0.036,0.028,0.021$, and 0.012 , respectively. This showed that these indicators

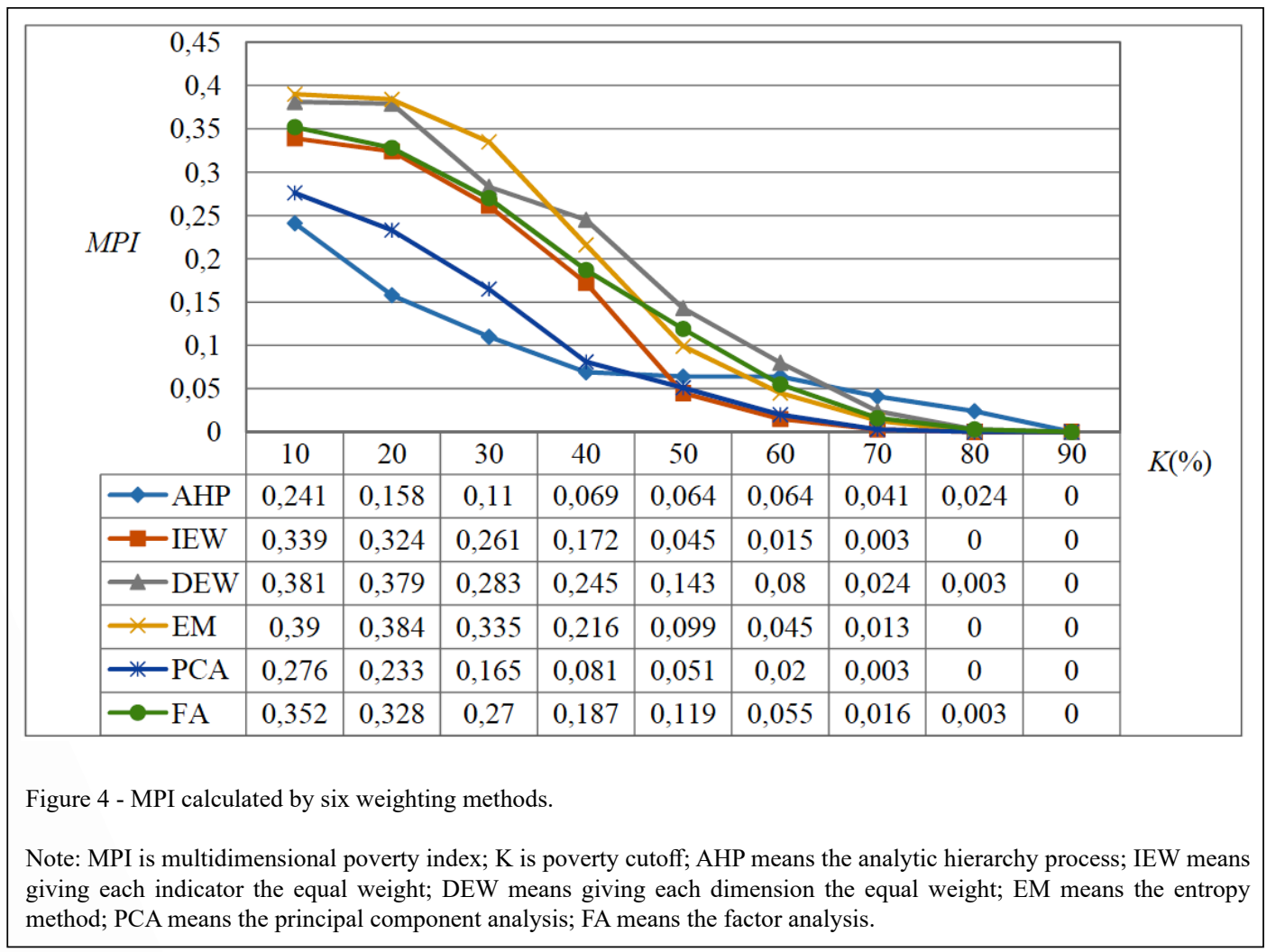

Ciência Rural, v.49, n.8, 2019. 
Table 5 - Correlation coefficients of MPI between different weight methods.

\begin{tabular}{lcccccc}
\hline & AHP & IEW & DEW & EM & PCA & FA \\
\hline AHP & 1 & & & & & \\
IEW & 0.898 & 1 & & & & \\
DEW & 0.899 & 0.977 & 1 & & & \\
EM & 0.890 & 0.994 & 0.987 & 1 & & \\
PCA & 0.956 & 0.978 & 0.959 & 0.971 & 1 & \\
FA & 0.916 & 0.986 & 0.994 & 0.995 & 0.977 & 1 \\
\hline
\end{tabular}

Note: AHP: analytic hierarchy process; IEW: indicator equal weight; DEW: dimension equal weight; EM: entropy method; PCA: principal component analysis; FA: factor analysis.

are the secondary causes of MPI among FHH.

Contribution rate of the household electricity supply $\left(x_{10}\right)$ and the number of consumer durables $\left(x_{12}\right)$ is 0.007 and 0.004 , respectively. This indicated that these two indicators have little influence on the multidimensional poverty of $\mathrm{FHH}$.

\section{Contribution of each dimension to MPI}

Contribution of each dimension to MPI when $K=30 \%$ is shown in table 7 . The contribution of each dimension to $M P I$ when $K=30 \%$ is different in all methods. The greatest contributor to $M P I$ in the DEW method is the dimension of health, the second contributor is education, and the last contributor is living standard, while the value of contribution of health and education to MPI is similar. This reflected that the two dimensions of health and education are more important for anti-poverty reform in Gansu Tibetan area of China than the living standard.

\section{CONCLUSIONS AND POLICY IMPLICATIONS}

This paper measured the multidimensional poverty situation of FHH located in the Tibetan areas of the Gansu Province, China by using the AlkireFoster method. Twelve indicators were included in the multidimensional poverty indicator system. Results showed that 1) in the single indicator poverty, the adult family members received at least 9th grade education ( $x 3)$, the home toilet type $(x 7)$, and the labor availability $(x 2)$ show a higher incidence of poverty, 2) in multidimensional poverty, many FHH in the Tibetan areas of the Gansu Province are facing multidimensional poverty, but the proportion in extreme poverty is very small, and 3) from the perspective of contribution rate, adult family members received at least 9th grade education $\left(x_{3}\right)$, labor availability $\left(x_{2}\right)$, self-health assessment $\left(x_{1}\right)$, home toilet type $\left(x_{7}\right)$, and school-age children dropout rate $\left(x_{4}\right)$ occupied the top five positions.

The results have several policy implications: first, policymakers should adjust the

Table 6 - Contribution of each indicator to $M P I$ when $K=30 \%$.

\begin{tabular}{|c|c|c|c|c|c|c|c|}
\hline Dimension & Indicator & AHP & IEW & DEW & EM & PCA & FA \\
\hline \multirow{2}{*}{ Health } & Self-health assessment $\left(x_{1}\right)$ & 0.173 & 0.069 & 0.128 & 0.053 & 0.137 & 0.131 \\
\hline & Labor availability $\left(x_{2}\right)$ & 0.053 & 0.122 & 0.265 & 0.124 & 0.264 & 0.121 \\
\hline \multirow[t]{2}{*}{ Education } & $\begin{array}{l}\text { Adult family members received at least } \\
\text { 9th grade education }\left(x_{3}\right)\end{array}$ & 0.195 & 0.200 & 0.333 & 0.241 & 0.044 & 0.287 \\
\hline & School-age children dropout $\left(x_{4}\right)$ & 0.388 & 0.027 & 0.050 & 0.017 & 0.015 & 0.038 \\
\hline \multirow{8}{*}{ Living standard } & Per capita housing area $\left(x_{5}\right)$ & 0.008 & 0.095 & 0.038 & 0.090 & 0.052 & 0.113 \\
\hline & Housing quality $\left(x_{6}\right)$ & 0.028 & 0.033 & 0.012 & 0.022 & 0.111 & 0.025 \\
\hline & Home toilet type $\left(x_{7}\right)$ & 0.040 & 0.192 & 0.078 & 0.233 & 0.164 & 0.093 \\
\hline & $\begin{array}{l}\text { Animal shed is within the house where } \\
\text { people live }\left(x_{8}\right)\end{array}$ & 0.041 & 0.051 & 0.021 & 0.040 & 0.084 & 0.001 \\
\hline & Sources of drinking water $\left(x_{9}\right)$ & 0.042 & 0.085 & 0.028 & 0.077 & 0.015 & 0.072 \\
\hline & Household electricity supply $\left(x_{10}\right)$ & 0.006 & 0.019 & 0.007 & 0.012 & 0.038 & 0.009 \\
\hline & Household fuel supply $\left(x_{11}\right)$ & 0.023 & 0.098 & 0.036 & 0.087 & 0.062 & 0.103 \\
\hline & Number of consumer durables $\left(x_{12}\right)$ & 0.002 & 0.011 & 0.004 & 0.005 & 0.014 & 0.008 \\
\hline
\end{tabular}

Note: $M P I$ is the multidimensional poverty index; $K$ is the poverty cutoff; AHP: analytic hierarchy process; IEW: indicator equal weight; DEW: dimension equal weight; EM: entropy method; PCA: principal component analysis; FA: factor analysis. 
Table 7 - Contribution of each dimension to MPI when $K=30 \%$.

\begin{tabular}{lcccccc}
\hline Dimension & AHP & IEW & DEW & EM & PCA & FA \\
\hline Health & 0.226 & 0.191 & 0.393 & 0.177 & 0.401 & 0.252 \\
Education & 0.583 & 0.227 & 0.383 & 0.258 & 0.059 & 0.325 \\
$\begin{array}{l}\text { Living } \\
\text { standard }\end{array}$ & 0.190 & 0.584 & 0.224 & 0.566 & 0.540 & 0.424 \\
\hline
\end{tabular}

Note: MPI is the multidimensional poverty index; $\mathrm{K}$ is the poverty cutoff; AHP: analytic hierarchy process; IEW: indicator equal weight; DEW: dimension equal weight; EM: entropy method; PCA: principal component analysis; FA: factor analysis.

targeting mechanism to ensure an effective way to alleviate poverty. After the early implementation and successful alleviation of poverty at a large-scale in the country, relatively well-off Tibetan farmers and herdsmen have also overcome poverty. The remaining poor people are generally in a state of abject poverty (WANG, 2016). Additionally, their poverty is multidimensional according to our findings. It is challenging to get these people out of poverty. Relying on the trickle-down effect of economic development to help poor people out of poverty has not been effective. Therefore, policymakers need to identify the poor from a multidimensional perspective. In fact, the Chinese government has been taking this approach, but still the approach needs to be strengthened by finding the types, the extent, and the depth of poverty in the Tibetan areas.

Second, based on multidimensional poverty, policymakers should focus on an effective program based on the highest contributing indicators and the highest contributing dimensions. Judging from the contribution rate of the poverty dimension, the key work of poverty alleviation in rural areas of the Gansu Tibetan region should focus on developing basic education: it is necessary to develop more basic education and raise the education level of farmers and herdsmen in the Tibetan areas to improve human capital. The study of HUA et al. (2017) also supported this viewpoint. It may be beneficial to build more schools and attract qualified teachers by paying a higher salary so that children in FHH can learn and become educated in important life skills. Health is also important to FHH. It is also necessary to improve the living conditions of poor FHH.

Third, it is necessary to stabilize the poverty rate among FHH. Judging from the current absolute poverty standards in China, the amount of income per household needs to exceed a certain limit. From the perspective of multi-dimensional poverty alleviation, poverty reduction also means crossing over the respective poverty thresholds in multiple dimensions, including housing, drinking water, health, and education. This calls for an MPI assessment to get rid of poverty by implementing effective policies. According to the Sen's capability approach (SEN, 1999), income is the most direct and dominant variable of poverty alleviation; however, upgrading capability is a more reliable way to alleviate poverty (SAITO, 2003). Therefore, in a poverty alleviation assessment, indicators related to capability should be given a higher weight. Moreover, professional thirdparties should implement the poverty alleviation assessment to uphold principles of equity and fairness. Stakeholder mechanisms must be established to avoid stakeholders manipulating results of the assessment.

As pointed out in the introduction section, Tibetans in China live in certain pockets of several provinces. However, resource limitations and the importance of the geographical area forced us to investigate the multidimensional poverty of only farm and herder households in the Gansu Tibetan region. Future studies can collect data in different provinces where Tibetans live and make a comparative analysis of the multidimensional poverty status of Tibetan farm and herder households across these provinces. Additionally, future research should be conducted to identify the causal effects of a treatment variable and other control variables affecting poverty in the study area using randomized control treatment or quasiexperimental methods.

\section{ACKNOWLEDGMENTS}

The Soft Science Project of Science and Technology Department of Sichuan Province, China "Study on the Synergistic Promotion Mechanism of Rural Revitalization and Precision Poverty Alleviation Strategy in Ethnic Minority Areas (Project No. 2019JDR0178)", Sichuan University Basic Scientific Research Project "Study on the Relative Poverty of Urban Migrant Workers (Project No. 2019ZIYAN-XIKAI004)", Project of Sichuan Center for Rural Development Research "Study on Precision and Stability of Poverty Alleviation in Sichuan Ethnic Areas". Paudel's time in this paper was supported by the USDA NIFA grants LAB\#94382 and LAB\#94358.

\section{DECLARATION OF CONFLICT OF INTERESTS}

The authors declare no conflict of interest. The founding sponsors had no role in the design of the study; in the collection, analyses, or interpretation of data; in the writing of the manuscript, and in the decision to publish the results. 


\section{AUTHORS' CONTRIBUTIONS}

All authors have made contributions to the present research. Fan Yang was fully engaged in the paper writing and revision. Krishna P. Paudel offered great insights in directing the method needed to do the data analyses. Yao Jiang dedicated time in data processing. Tianhui Zhuang played a full supervisory role in the research. All authors critically revised the manuscript and approved of the final version.

\section{REFERENCES}

ALKIRE, S. Choosing dimensions: the capability approach and multidimensional poverty. In: Kakwani, N.; Silber, J. (Eds.), The Many Dimensions of Poverty. London: Palgrave Macmillan, 2007. 89-119p. Available from: <https://link.springer.com/ chapter/10.1057/9780230592407_6>. Accessed: May, 10, 2018.

ALKIRE, S. et al. Multidimensional poverty measurement for EUSILC countries. OPHI Research in Progress Series 36c, Oxford University, 2014. Available from: <https://www.researchgate.net/ publication/279531929_Multidimensional_poverty_measurement for_EU-SILC_countries>. Accessed: May, 10, 2018.

ALKIRE, S.; FOSTER, J. Counting and multidimensional poverty measurement. Journal of Public Economics, v.95, n.7, p.476-487, 2011a. Available from: <https://www.sciencedirect.com/science/ article/pii/S0047272710001660?via\%3Dihub>. Accessed: May, 10, 2018. doi: 10.1016/j.jpubeco.2010.11.006.

ALKIRE, S.; FOSTER, J. Understandings and misunderstandings of multidimensional poverty measurement. Journal of Economic Inequality, v.9, n.2, p.289-314, 2011b. Available from: <https:// link.springer.com/content/pdf/10.1007\%2Fs10888-011-9181-4. pdf>. Accessed: May, 10, 2018. doi: 10.1007/s10888-011-9181-4.

ALKIRE, S. et al. Multidimensional poverty measurement and analysis: Chapter 3 - Overview of methods for multidimensional poverty assessment. Alkire, S.; Foster, J. E.; Seth, S.; Santos, M. E.; Roche, J. M.; Ballon, P. 2015. Multidimensional Poverty Measurement and Analysis. Oxford University Press, Oxford. Available from: $<$ https://ssrn.com/abstract $=2564782>$. Accessed: May, 10, 2018

ALKIRE, S.; ROBLES, G. Multidimensional poverty index Summer 2017: Brief methodological note and results. OPHI MPI Methodological Notes 44, Oxford Poverty and Human Development Initiative, 2017. Available from: $<$ https://www.ophi. org.uk/wp-content/uploads/OPHIMethNote 44 Summer 2017. pdf $>$. Accessed: May, 10, 2018.

ALKIRE, S. et al. Multidimensional Poverty Measurement and Analysis. Oxford University Press, USA, 2015b.

ALKIRE, S.; SANTOS, M. E. Measuring acute poverty in the developing world: Robustness and scope of the multidimensional poverty index. World Development, v.59, p.251-274, 2014 Available from: <https://www.sciencedirect.com/science/article/ pii/S0305750X14000278>. Accessed: May, 11, 2018. doi: 10.1016/j.worlddev.2014.01.026.

ALKIRE, S.; SETH, S. Measuring multidimensional poverty in India: a new proposal. OPHI Working Paper No. 15, 2008. Available from: $<$ https://ssrn.com/abstract $=1815355>$. Accessed: May, 11, 2018
BATANA, Y. Multidimensional measurement of poverty in SubSaharan Africa. OPHI Working Paper, No.13, 2008. Available from: $<$ https://ora.ox.ac.uk/objects/uuid:754e41b3-f315-410d-8ed11b28cf71644f>. Accessed: May, 11, 2018.

BATTISTON, D. et al. Income and beyond: multidimensional poverty in six Latin American countries. Social Indicators Research, v.112, n.2, p.291-314, 2013. Available from: <https:// link.springer.com/article/10.1007/s11205-013-0249-3>. Accessed: May, 11, 2018. doi: 10.1007/s11205-013-0249-3.

BLUNDELL, R. et al. Income inequality and the labour market in Britain and the US. Journal of Public Economics, v.162, p.48-62, 2018. Available from: <https://www.sciencedirect.com/science/ article/pii/S0047272718300562>. Accessed: May, 11, 2018. doi: 10.1016/j.jpubeco.2018.04.001.

CHAKRAVARTY, S. et al. On the Watts multidimensional poverty index and its decomposition. World Development, v.36, n.6, p.1067-1077, 2008. Available from: <https://www.sciencedirect. com/science/article/pii/S0305750X08000430>. Accessed: May, 11, 2018. doi: 10.1016/j.worlddev.2007.10.003.

DEUTSCH, J.; SILBER, J. Measuring multidimensional poverty: An empirical comparison of various approaches. Review of Income and Wealth, v.51, n.1, p.145-174, 2005. Available from: <https://www. ingentaconnect.com/content/bpl/roiw/2005/00000051/00000001/ art00006>. Accessed: May, 11, 2018. doi: 10.1111/j.14754991.2005.00148.x.

DU, M. Y.; YU, Z. Ecological poverty in ecological fragile regions from the perspective of Ecological Capital: A case study of Tibetan areas of Sichuan Province. Chinese Journal of Theory Monthly, n.2, p.176-179, 2013. (in Chinese).

DU, M. Y.; ZHAO, X. Anti-poverty mechanism of agricultural and pastoral regions in Tibetan areas of China. Chinese Journal of Guizhou Social Sciences, n.8, p.82-86, 2010. (in Chinese).

FOSTER, J. et al. A class of decomposable poverty measures. Econometrica, v.52, n.3, p.761-766, 1984. Available from: $<$ https://search.proquest.com/docview/214653621?OpenUrlRefId =info:xri/sid:baidu\&accountid=13854>. Accessed: May, 11, 2018. doi: $10.2307 / 1913475$.

FOGGIN, J. M. Depopulating the Tibetan grasslands: National policies and perspectives for the future of Tibetan herders in Qinghai Province, China. Mountain Research and Development, v.28, n.1, p.26-31, 2008. Available from: <https:// search.proquest.com/docview/211232200/fulltextPDF/C0FDF49 FF8C04C77PQ/1?accountid=13854>. Accessed: May, 11, 2018. doi: $10.1659 / \mathrm{mrd} .0972$.

GENG, B. J. et al. The driving mechanism and micro mechanism of tourism poverty relief in Tibetan areas of Sichuan Province. Chinese Journal of Guizhou Ethnic Studies, n.4, p.157-160, 2016. (in Chinese).

GUO, J. Y.; WU, G. B. Multidimensional poverty measurement based on different indexes and weights: A case of poor counties in Shanxi Province of China. Chinese Rural Economy, n.2, p.12-20, 2012. (in Chinese).

HAGENAARS, A. A class of poverty indices. International Economic Review, v.28, n.3, p.583-607, 1987. Available from: $<$ https://www.jstor.org/stable/2526568? origin=crossref\&seq $=2$ 
\#metadata_info_tab_contents>. Accessed: May, 12, 2018. doi: $10.2307 / 2 \overline{5} 26568$.

HUA, X. et al. Evaluating the role of livelihood assets in suitable livelihood strategies: Protocol for anti-poverty policy in the Eastern Tibetan Plateau, China. Ecological Indicators, v.78, p.62-74, 2017. Available from: $<$ https://www.sciencedirect.com/science/ article/pii/S1470160X17301176>. Accessed: May, 12, 2018. doi: 10.1016/j.ecolind.2017.03.009.

JOLLIFFE, I. et al. Simplified EOFs-three alternatives to rotation. Climate Research, v.20, n.3, p.271-279, 2002. Available from: $<$ https://www.int-res.com/articles/cr2002/20/c020p271.pdf $>$. Accessed: May, 12, 2018. doi: 10.3354/cr020271.

LAN, H. P.; YANG, F. Analysis of the influence of basic public services on poverty reduction in Tibetan areas of Sichuan Province. Chinese Journal of Sichuan Agricultural University, v.34, n.1, p.115-120, 2016. (in Chinese).

LI, X. P.; WANG, M. Analysis on village social stratification and poverty mechanism of farmers and herdsmen under the capital conversion perspective: an empirical study based on $\mathrm{Y}$ village in GZ Tibetan Autonomous Prefecture. Chinese Journal of SouthCentral University for Nationalities, n.4, p.76-81, 2015. (in Chinese).

LI, Y. Z. Tibetan poverty alleviation continues to face arduous tasks: findings based on the investigation of poverty in Litang County of Sichuan Province, China. Chinese Journal of Reform of Economic System, n.1, p.147-150, 2006. (in Chinese).

LIAO, G. R. Analysis on poverty and poverty alleviation in Tibetan areas of Sichuan Province. Chinese Journal of Rural Economy, n.1, p.53-55, 2014a. (in Chinese)

LIAO, G. R. Educational expectation and poverty trap: an explanation for the persistent poverty of Tibetan herdsmen in China. Chinese Journal of Southwest University for Nationalities, n.6, p.198-201, 2014b. (in Chinese).

LIAO, G. R.; LI, J. H. A study of poverty in Tibetan areas of Sichuan Province from the perspective of social capital. Chinese Journal of Southwest University for Nationalities, v.33, n.6, p.56-58, 2009. (in Chinese).

LIU, Z. et al. Using solar house to alleviate energy poverty of rural Qinghai-Tibet region, China: A case study of a novel hybrid heating system. Energy and Buildings, v.178, p.294-303, 2018. Available from: <https://www.sciencedirect.com/science/ article/pii/S0378778818317110>. Accessed: Dec. 15, 2018. doi: 10.1016/j.enbuild.2018.08.042.

LUO, L.; XIE, L. S. Research on the development of Tibetan characteristic advantage industry under the background of precise poverty alleviation. Chinese Journal of Qinghai Social Sciences n.5, p.9-14, 2016. (in Chinese).

MIHAI, M. et al. Education and poverty. Procedia Economics and Finance, v.32, p.855-860, 2015. Available from: $<\mathrm{https}$ :// www.sciencedirect.com/science/article/pii/S2212567115015324>. Accessed: May, 15, 2018. doi: 10.1016/S2212-5671(15)01532-4.

MORRIS, M. D. Measuring the condition of the world's poor: The physical quality of life index. Pergamon Press, New York, 1979.
MULAIK, S. A. Foundations of Factor Analysis. Chapman \& Hall/CRC, 2010.

PERES-NETO, P. R. et al. Giving meaningful interpretation to ordination axes: Assessing loading significance in principal component analysis. Ecology, v.84, n.9, p.2347-2363, 2003. Available from: $<$ https://esajournals.onlinelibrary.wiley.com/doi/full/10.1890/00-0634>. Accessed: Jun. 10, 2018. doi: 10.1890/00-0634.

QIN, Z. M.; LU, H. W. Management of Tibetan herdsmen livelihood differentiation and ability poverty: Taking the Cuoma County in the west of China Sichuan Province as an example. Chinese Journal of Population of Northwest China, v.33, n.6, p.107-110, 2012. (in Chinese).

RACINE, A. D. Child poverty and the health care system. Academic Pediatrics, v.16, n.3, p.S83-S89, 2016. Available from: $<$ https://www. sciencedirect.com/science/article/pii/S1876285915003757?via\%3Dihub>. Accessed: Jun. 10, 2018. doi: 10.1016/j.acap.2015.12.002.

ROGAN, M. Gender and multidimensional poverty in South Africa: applying the global multidimensional poverty index (MPI). Social Indicators Research, v.126, n.3, p.987-1006, 2016. Available from: $<$ https://link.springer.com/article/10.1007/s11205-015-0937-2>. Accessed: Jun. 10, 2018. doi: 10.1007/s11205-015-0937-2.

ROSSETTO, A. et al. Harnessing tourism as a means of poverty alleviation: Using the right language or achieving outcomes. Tourism Recreation Research, v.32, n.1, p.49-58, 2007. Available from: <https://www.tandfonline.com/doi/pdf/10.1080/02508281.2 007.11081523? needAccess $=$ true $>$. Accessed: Jun. 12, 2018. doi: 10.1080/02508281.2007.11081523.

SAATY, R. W. The analytic hierarchy process-What it is and how it is used. Mathematical Modelling, v.9, n.3-5, p.161-176, 1987. Available from: <https://www.sciencedirect.com/science/ article/pii/0270025587904738>. Accessed: Jun. 12, 2018. doi: 10.1016/0270-0255(87)90473-8.

SAITO, M. Amartya Sen's capability approach to education: A critical exploration. Journal of Philosophy of Education, v.37, n.1, p.17-33, 2003. Available from: <https://onlinelibrary.wiley. com/doi/full/10.1111/1467-9752.3701002>. Accessed: Jun. 12, 2018. doi: 10.1111/1467-9752.3701002.

SEN, A. K. Commodities and Cabilities. North-Holland, Amsterdam, 1985.

SEN, A. K. Development as Freedom. Oxford University Press, Oxford, 1999

SHEN, M. Y. The multi-dimensional restraint and solution strategy in Tibetan areas of Sichuan Province, China. Chinese Journal of Rural Economy, n.6, p.62-66, 2015. (in Chinese).

UNDP. Human Development Report 1997, 1997. Available from: $<$ http://hdr.undp.org/en/content/human-development-report-1997>. Accessed: Jun. 15, 2018.

UNDP. Human Development Report 2010, 2010. Available from: $<$ http://hdr.undp.org/en/content/human-development-report-2010>. Accessed: Jun. 15, 2018.

WANG, X. L.; ALKIRE, S. Multidimensional poverty measurement in China: Estimation and policy implications. Chinese Journal of Chinese Rural Economy, n.12, p.4-10, 2009. (in Chinese). 
WANG, Y. L. A study on poverty alleviation at special types regions in Hainan Tibetan Autonomous Prefecture of Qinghai Province. Chinese Journal of Qinghai Social Sciences, n.6, p.2126, 2016. (in Chinese).

YAN, J. et al. Adaptation strategies to pasture degradation: Gap between government and local nomads in the eastern Tibetan Plateau. Journal of Geographical Sciences, v.21, n.6, p.11121122, 2011. Available from: <https://link.springer.com/content/ pdf/10.1007\%2Fs11442-011-0904-z.pdf>. Accessed: Jun. 15, 2018. doi: 10.1007/s11442-011-0904-Z.

YANG, J. W. The present situation and causes of poverty in Tibetan areas of Sichuan Province. Chinese Journal of Tibetan Studies, n.4, p.55-65, 2005. (in Chinese).

YU, J. Multidimensional poverty in China: Findings based on the CHNS. Social Indicators Research, v.112, n.2, p.315-336, 2013. Available from: $<\mathrm{https} / / /$ link.springer.com/article/10.1007/s11205-0130250-x> . Accessed: Jun. 20, 2018. doi: 10.1007/s11205-013-0250-x.

ZHANG, H. The poverty trap of education: Education-poverty connections in Western China. International Journal of Educational Development, v.38, n.3, p.47-58, 2014. Available from: <https:// www.sciencedirect.com/science/article/pii/S0738059314000431>. Accessed: Jun. 20, 2018. doi: 10.1016/j.ijedudev.2014.05.003.
ZHANG, Q. H.; ZHOU, Q. A. Multidimensional approach to poverty measurement and its application in China. Chinese Journal of China Soft Science, n.7, p.29-41, 2015. (in Chinese).

ZHANG, X. Y.; FENG, H. X. Multidimensional poverty analysis of floating women: Based on the survey of 451 domestic service practitioners in Beijing. Chinese Journal of Economic Review, n.3, p.95-107, 2016. (in Chinese).

ZHENG, B. Aggregate poverty measures. Journal of Economic Surveys, v.11, n.2, p.123-162, 1997. (in Chinese).

ZHU, L. Women's health problem in Qinghai, Gansu, Yunnan Agricultural Districts. Chinese Journal of Management World, n.10, p.59-74, 2010. (in Chinese).

ZHUANG, T. H. Research on income, structure and gap of farmers and herdsmen in Tibetan areas of Sichuan Province. Chinese Journal of Journal of Southwest University for Nationalities, n.6, p.107-110, 2016. (in Chinese).

ZILIAK, J. P. Income, program participation, poverty, and financial vulnerability: Research and data needs. Journal of Economic and Social Measurement, v.40, n.1-4, p.27-68, 2015. Available from: $<$ http://gattonweb.uky.edu/Faculty/Ziliak/Ziliak_JESM_2015. pdf $>$. Accessed: Jun. 20, 2018. doi: 10.3233/jem-150397. 